A. Johnson and Mr. L. G. Johnson, lecturers in the Departments of Economics and Extra-Mural Studies ; Mr. Edward Broadhead, lecturer in zoology; Mr. J. D. Jonkins, lecturer in mining; Mr. H. J. King, lecturer in surveying; Dr. W. J. Allen and Dr. R. A. Kenney, lecturers in physiology; Mr. S. Dagley, lecturer in biochemistry; Mr. G. A. Nelson, lecturer in pharmacognosy.

The number of full-time students enrolled for the present session is 2,804 ; the number of ex-Service students at present in the University is approximately 1,200. The present total of students compares with 1,736 in 1938 ; the number of arts students has increased very markedly owing to the number of students returning to complete courses interrupted by national service, but apart from this the increase is fairly uniformly spread over all departments and faculties.

\section{University of Sheffield : Appointments}

THe following appointments have been made in the University of Sheffield: Dr. A. S. C. Lawrence, senior lecturer in physical chemistry ; Dr. H. J. Tress, lecturer in glass technology; H. Graetzer, assistant lecturer in mathematics; G. H. Jowett, assistant lecturer in statistics in the Department of Mathematics ; J. R. Beattie, assistant lecturer in physics; Douglas W. Riley, assistant lecturer in chomistry; H. J. Whiteley, assistant lecturer in pathology.

The following resignations have been announced: Dr. J. Sinclair, senior lecturer in mining, who has been appointed to the chair of mining at University College, Cardiff; Dr. F. Bielschowsky, cancer research worker in the Department of Pathology under the British Empire Cancer Campaign, who has been appointed director of cancer research for New Zealand.

\section{The Night Sky in November}

NEW moon occurs on Nov. 12d. 20h. 0lm., U.T., and full moon on Nov. $28 \mathrm{~d} .08 \mathrm{~h}$. $45 \mathrm{~m}$. The following conjunctions with the moon take place: Nov. 6d. 03h., Mars $4^{\circ}$ S.; Nov. 6d. 07h., Saturn $5^{\circ}$ S. ; Nov. 11d. 20h., Mercury $0 \cdot 03^{\circ}$ S. ; Nov. 14d. 0lh., Jupiter $2^{\circ}$ N. ; Nov. 14 d. 10 h., Venus $1^{\circ}$ N. In addition to these conjunctions with the moon, the following conjunctions also take place: Nov. 9d. 14h., Venus in conjunction with Jupiter, Venus $0.9^{\circ} \mathrm{S}$.; Nov. 11d. $18 \mathrm{~h}$., Mars in conjunction with Saturn, Mars $0.9^{\circ} \mathrm{N}$. Mercury is in inferior conjunction on Nov. 5 and becomes a morning star later in the month, rising at 5h. $40 \mathrm{~m}$., and $6 \mathrm{~h}$. at the middle and end of the month, respectively. Venus, an evening star, sets about $17 \mathrm{~h}$. throughout November and can be seen very low in the western sky. Mars, in the constellation of Leo, rises at $23 \mathrm{~h} .08 \mathrm{~m}, 22 \mathrm{~h} .52 \mathrm{~m}$, and $22 \mathrm{~h} .25 \mathrm{~m}$., at the beginning, middle and end of the month respectively, and is close to Regulus towards the end of November. Jupiter sets in the early evening hours and is unobservable. Saturn rises at $23 \mathrm{~h}$. $38 \mathrm{~m}$., and $21 \mathrm{~h}$. $50 \mathrm{~m}$. at the beginning and end of the month, respectively, and can be seen in the constellation of Leo, fairly close to Mars. Occultations of stars brighter than magnitude 6 are as follows: Nov. 1d. 04h. $25 \cdot 5 \mathrm{~m}$., v Taur. $(D)$; Nov. 1d. 05h. $08 \cdot 9 \mathrm{~m}$., v Taur. $(R)$; Nov. Id. $19 \mathrm{~h}$. $53 \cdot 0 \mathrm{~m} ., 103$ Taur. $(R)$; Nov. 2d. 05h. $33 \cdot 2 \mathrm{~m} ., 118$ Taur. $f .(R)$; Nov. 7d. 04h. $32 \cdot 1 \mathrm{~m} ., 46$ Leon. $(R)$; Nov. 21d. 18h. 17.3m., $\tau$ Aqar. $(D)$; Nov. 26d. 20h. 37.0m., $\sigma$ Arie $(D)$; Nov. 29d. 23h. 33.0m., 139 Taur. $(R) . \quad D$ and $R$ refer to disappearance and reappearance, respectively, and the latitude of Greenwich is assumed. There will be an annular eclipse of the sun on Nov. 12, invisible at Greenwich.

\section{Announcements}

Prof. Arthur Holimes, regius professor of geology in the University of Edinburgh, has been elected a foreign member of the Royal Swedish Academy of Sciences.

THE Kelvin Medal Award Committee, consisting of the presidents of the Institutions of Civil Engineers, Mechanical Engineers, Electrical Engineers, Naval Architects, Mining and Metallurgy, Mining Engineers, and Engineers and Shipbuilders in Scotland, and the Iron and Steel Institute, has awarded the Kelvin Gold Medal for 1947 to Air Commodore F. G. Whittlo, in recognition of the eminent services he has rendered to engineering science in those branches of engineering work with which Lord Kelvin was especially identified. The Medal is normally presented triennially, but the last award was made in 1938 to Sir J. J. Thomson.

Dr. Joskef Aronson, of the United States Bureau of Indian Affairs, has been awarded the Alvarenga Prize of 1947 of the College of Physicians of Philadelphia, in recognition of his studies on the evaluation of $B C G$ vaccine in the control of tuberculosis.

AT the invitation of the British National Committee, the fourth plenary World Power Conference will be held in London in 1950.

THE International Union of Biological Sciences, with the financial support of the United Nations Educational, Scientific and Cultural Organisation, is arranging a symposium on the role of trace elements in plant physiology, to be held at Rothamsted Experimental Station during November 5-6, 1947. Seventeen research workers from Australia, Denmark, Finland, France, Great Britain, Netherlands, Norway, Sweden, Switzerland and the United States have accepted invitations to attend. The report on this symposium will be published by the International Union.

THE Linnean Society of London, in conjunction with the Systematics Association, is organising a course of twelve weekly lectures on the "Principles and Methods of Taxonomy". Lectures will be given in the rooms of the Linnean Society on Wednesdays at 5.30 p.m., the first lecture being on October 29 . Leading plant and animal taxonomists are contributing to the course, which is open to advanced students of biology. Further information can be obtained from the Assistant Secrotary, Linnean Society of London, Burlington House, Piccadilly, London, W.1.

A Faraday Socrexy general discussion on "The Physical Chemistry of Process Metallurgy" will be held in the latter half of September 1948. It is intended that the discussion should be devoted to the thermodynamies and kinetics of the high-tem. perature reactions involved in smelting and refining, but excluding reactions which occur in mechanical working and heat treatment, and also electrochemical processes in aqueous solutions. Thermodynamics will include thermochemical, free energy and equilibrium studies, and kinetics will include both chemical reactions and diffusion processes. Prospective contributors should forward to the Secretary of the Society summaries of any papers they would like to submit not later than February 1. 